\title{
Enhancement of concrete brick with marble waste
}

\author{
Zainelabdin Khalid Zainelabdin Elfaki* \\ Mining House Company, General management, Riyadh, Saudi Arabia
}

\begin{abstract}
This experimental study of the reinforcement of concrete brick with marble waste aims to show the influence of partial replacement of cement with marble waste on the workability and compressive strength of concrete. Three replacement percentages of $10 \%, 20 \%$ and $30 \%$ were used with different curing times of 7, 14and 28 days. For the optimum results and in order to reduce the effect of human errors on the study accuracy, two specimens were prepared for each percentage and curing time. For this study, marble powder from Mining House Company in Saudi Arabia was used. After doing all the experiment works it was observed that the replacement of Concrete brick with marble waste enhanced the loading strength and the workability of prepared concrete bricks. It was also observed that the $20 \%$ replacement of cement with marble waste is the best replacement percentage compared to the other replacement percentages. Marble waste from manufacturing companies either in powder, sludge or slabs form has serious bad effect on the environment. Furthermore, the usage of marble waste in such industries has many other benefits such as economical benefit of selling the marble wastes and saving the natural resources.
\end{abstract}

\section{Introduction}

Concrete is a vital ingredient in infrastructure development with its versatile and extensive applications. Concrete is the second largest material consumed by human beings after food and water as per WHO [1] (World Health Organization). As Cement is one of the concrete basic materials, today, utilization of blended cements is usually preferred due to their economical and Technical benefits and indirect advantages such as their ability of decreasing $\mathrm{CO} 2$ emissions by reducing clinker production in plants [2]. The world cement production has been increasing constantly since the early 1950s, especially in developing countries. World cement production was about 2100 million tons in 2004, with a yearly growth of about $7-8 \%$; it was doubled in less than 20 years. Asia has been the driving force with China and India currently the main cement producers (respectively: 930 million and 128 million tones or $44 \%$ and $6 \%$, respectively, of world production) [3].

Leaving the waste materials to the environment directly can cause environmental problem. Hence, many countries have been working on how to reuse the waste material so that they reduced hazards to the environment). The developed countries have strict rules to protect the environment whereas many developing countries have almost no rules to protect the environment against wastes. However, wastes can be used to produce new products or

\footnotetext{
*Corresponding author: zain998@yahoo.com
} 
can be used as admixtures so that natural sources are used more efficiently and the environment is protected from waste deposits. During the cutting process about $25 \%$ marble is resulted in dust [4].

One of the logical means for reduction of the waste marble masses calls for utilizing them in building industry itself. Some attempts have been made to find and assess the possibilities of using waste marble powder in mortars and concretes and results about strength and workability were compared with control samples of conventional cement-sand mortar/concrete. When marble powder is partially replaced in cement by weight, there is a marked reduction in compressive strength values of mortar mix with increasing marble powder content when compared with control sample at each curing age. Surprisingly, on increasing marble waste fine aggregate ratio i.e. when marble waste / granules are partially replaced in fine aggregate by weight then there is increase in compressive strength values of marble waste mortar at each curing age [5].

\section{Experimental procedure}

\subsection{Materials}

For this study, three replacement percentages of $10 \%, 20 \%$ and $30 \%$ were used with different curing times of 7, 14and 28 days. For the optimum results and in order to reduce the effect of human errors on the study accuracy, two specimens were prepared for each percentage and curing time.

\subsubsection{Aggregates}

\section{Fine aggregates}

Natural fine aggregates easily available, cheap price and widely used in construction were used.

Maximum size of $4 \mathrm{~mm}$ fine aggregates with $2775 \mathrm{~kg} / \mathrm{m} 3$ density was used for all specimen preparation. Fine aggregates take $2 / 7$ or $28.57 \%$ of the concrete weight as we are using the 1,2 and 4 mixing design.

\section{Course aggregates}

Natural course aggregates or Natural gravels (NG) commonly used for building applications were used.

Maximum size of $16 \mathrm{~mm}$ with $2733 \mathrm{~kg} / \mathrm{m} 3$ density Course aggregates was used. 4/7 or 57.14 $\%$ of concrete prepared is Course aggregates.

\subsubsection{Cement}

Normal grade Ordinary Portland cement (OPC) was used for all samples preparation. Table 1 shows the physical and chemical composition of OPC.

\subsubsection{Marble waste}

Dry powder marble waste was used from Mining House Company Riyadh, Saudi Arabia. Figure 1 shows the marble waste generated at marble factories. 


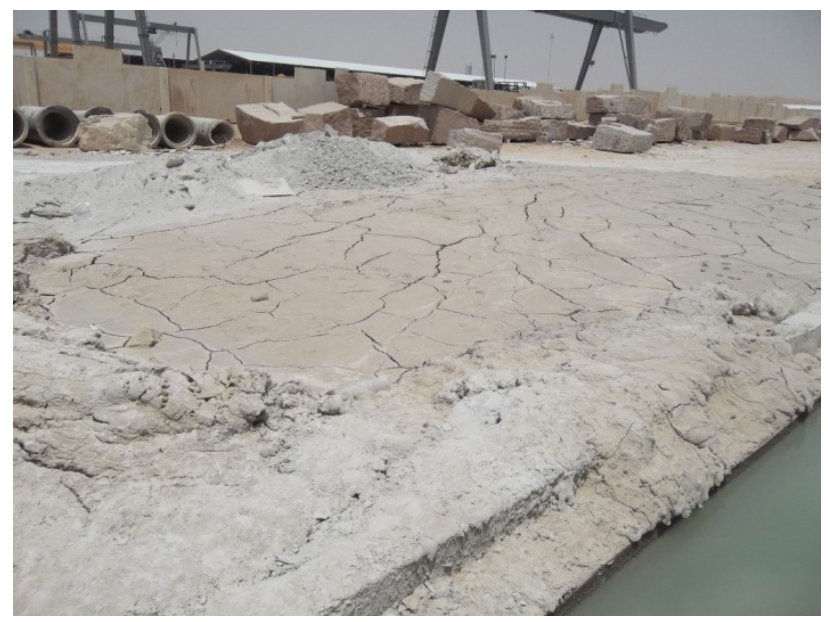

Fig. 1: Marble waste in factory.

Table 1: Physical properties and chemical composition of OPC.

\begin{tabular}{|c|c|c|c|}
\hline Test & Unit & British Standard & Result \\
\hline \multicolumn{4}{|c|}{ Chemical Composition } \\
\hline Lime Saturation factor (LSF) & $\%$ & $0.66-1.2$ & 0.94 \\
\hline Insoluble Residue (IR) & $\%$ & 5 max. & 0.2 \\
\hline Magnesium Oxide (MgO) & $\%$ & 5 max. & 1.5 \\
\hline Sulphate Contest $\left(\mathrm{SO}_{3}\right)$ & $\%$ & $3.5 \max$. & 3 \\
\hline Loss In Ignition (LOI) & $\%$ & $5 \max$. & 2 \\
\hline Chloride (CI) & $\%$ & $0.1 \max$. & 0.01 \\
\hline \multicolumn{4}{|c|}{ Physical Properties } \\
\hline Specific Surface Area & $\mathrm{M}^{2} / \mathrm{kg}$ & 225 min. & 347 \\
\hline Soundness & $\mathrm{mm}$ & 10 max. & 0.7 \\
\hline Setting time- Initial & Mins. & $45 \mathrm{~min}$. & 135 \\
\hline Setting time- Final & Mins. & 600 max. & 195 \\
\hline \multirow{2}{*}{$\begin{array}{l}\text { Compressive Strength for } \\
\text { Concrete Cubes } \quad 3 \text { days } \\
(1: 2: 4: 0.6)\end{array}$} & $\mathrm{N} / \mathrm{mm}^{2}$ & Not less than 11.5 & 21.8 \\
\hline & $\mathrm{N} / \mathrm{mm}^{2}$ & Not less than 26 & 43.3 \\
\hline
\end{tabular}

\subsection{Methods}

\section{Marble waste chemical composition}

The chemical composition of marble waste samples used was studied by using XRD (X-Ray Diffraction) analyzing device. Elements that marble waste consists of determines its chemical and physical properties which effects the mechanical

\section{Compressive Strength}

Compressive strength of concrete is the most important characteristic property which also affects other concrete properties. Water to Cement ratio and curing age are the main important factors influencing Compressive strength besides compaction. By measuring the load of concrete specimens, we can calculate the value of compressive strength either in Megapascal (MPa) or Pounds per square inch (psi).

Workability 
Workability is considered to be that property of concrete that determines its capacity to be placed and consolidated properly and to be finished without harmful segregation. It embodies such concepts as moldability, cohesiveness, and compactability.

Workability is affected by: the grading, particle shape, and proportions of aggregate; the amount and qualities of cement and other cementitious materials; the presence of entrained air and chemical admixtures; and the consistency of the mixture. Procedures in this Standard Practice permit these factors to be taken into account to achieve satisfactory placeability economically.

\subsubsection{Preparation of Specimens}

A replacement of the Cement quantity by 10,20 and $30 \%$ of marble waste and testing the effect of this replacement to the mechanical properties of the concrete made. Table 2 shows the specimens prepared with relevant details

Table 2: All specimens prepared with relevant details.

\begin{tabular}{|c|c|c|c|c|}
\hline & Specimen Number & $\begin{array}{c}\text { Replacement } \\
\text { percentage (\%) }\end{array}$ & $\begin{array}{c}\text { To be cured for } \\
\text { (days) }\end{array}$ & W/C \\
\hline $\mathbf{1}$ & S-10-7-1 & 10 & 7 & 0.55 \\
\hline $\mathbf{2}$ & S-10-7-2 & 10 & 7 & 0.55 \\
\hline $\mathbf{3}$ & S-10-14-1 & 10 & 14 & 0.55 \\
\hline $\mathbf{4}$ & S-10-14-2 & 10 & 14 & 0.55 \\
\hline $\mathbf{5}$ & S-10-28-1 & 10 & 28 & 0.55 \\
\hline $\mathbf{6}$ & S-10-28-2 & 10 & 28 & 0.55 \\
\hline $\mathbf{7}$ & S-20-7-1 & 20 & 7 & 0.55 \\
\hline $\mathbf{8}$ & S-20-7-2 & 20 & 7 & 0.55 \\
\hline $\mathbf{9}$ & S-20-14-1 & 20 & 14 & 0.55 \\
\hline $\mathbf{1 0}$ & S-20-14-2 & 20 & 28 & 0.55 \\
\hline $\mathbf{1 1}$ & S-20-28-1 & 20 & 28 & 0.55 \\
\hline $\mathbf{1 2}$ & S-20-28-2 & 20 & 7 & 0.55 \\
\hline $\mathbf{1 3}$ & S-30-7-1 & 30 & 7 & 0.55 \\
\hline $\mathbf{1 4}$ & S-30-7-2 & 30 & 14 & 0.55 \\
\hline $\mathbf{1 5}$ & S-30-14-1 & 30 & 14 & 0.55 \\
\hline $\mathbf{1 6}$ & S-30-14-2 & 30 & 28 & 0.55 \\
\hline $\mathbf{1 7}$ & S-30-28-1 & 30 & 28 & 0.55 \\
\hline $\mathbf{1 8}$ & S-30-28-2 & 30 & & \\
\hline & & & 285 \\
\hline
\end{tabular}

\section{Result and discussion}

\subsection{Chemical Composition}

The XRD analysis shows that marble waste mainly composed of Oxide based elements such as: Silica ( $\mathrm{SiO} 2)$, Calcium $(\mathrm{CaO})$, Phosphorus (P2O5), Magnesium (MgO), Potassium $(\mathrm{K} 2 \mathrm{O})$, Sodium $(\mathrm{Na} 2 \mathrm{O})$, Copper $(\mathrm{CuO})$, Manganese $(\mathrm{MnO})$, Zinc $(\mathrm{ZnO})$, Iron (Fe2O3), Aluminum (A12O3), Titanium ( $\mathrm{TiO} 2)$, and Sulphur trioxide (SO3). The next figures show the results of the analysis by XRD analyzing device. 


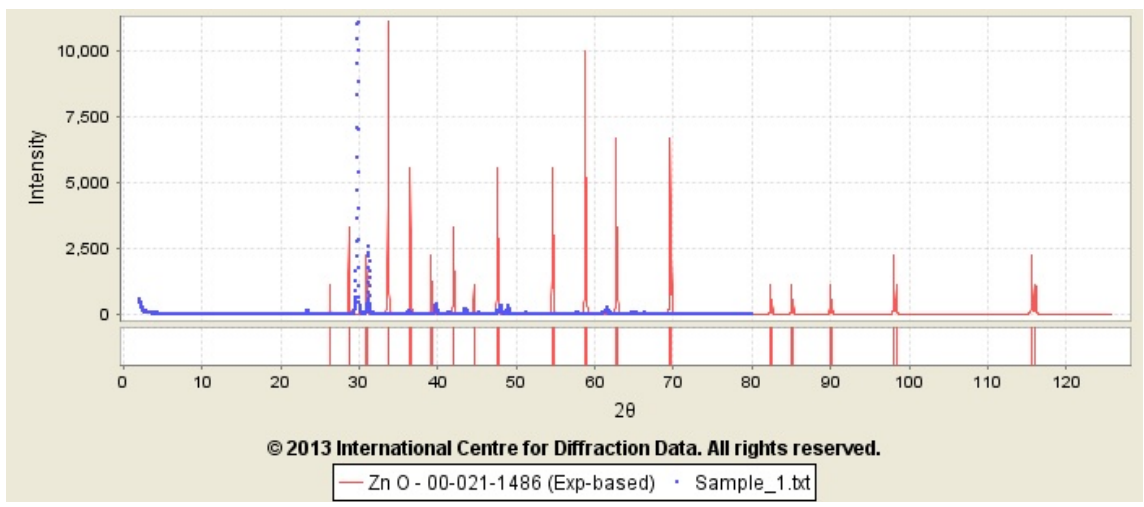

Fig. 2: $\mathrm{XRD}$ analysis for $\mathrm{ZnO}$ in marble waste sample.

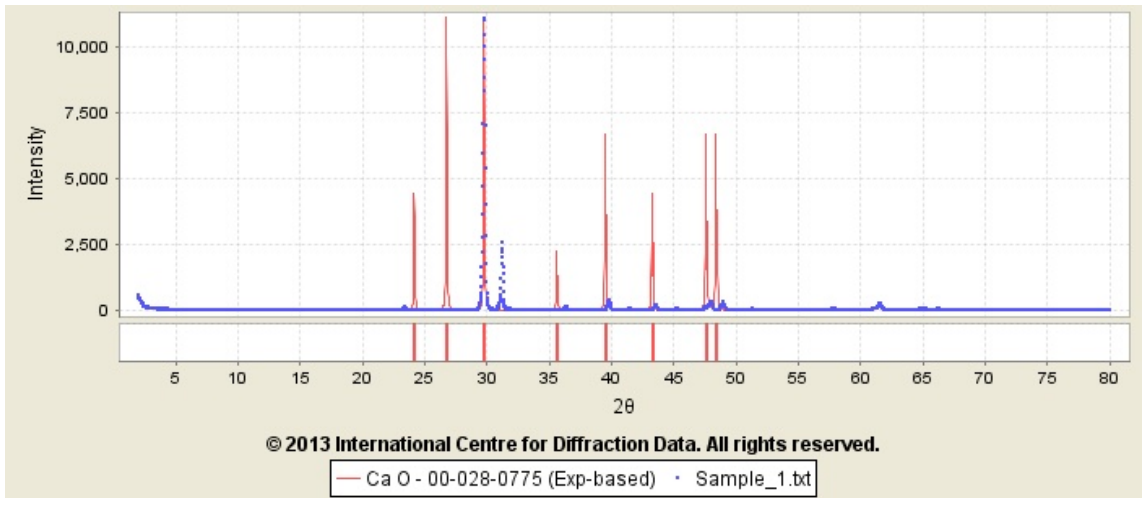

Fig. 3: $\mathrm{XRD}$ analysis for $\mathrm{CaO}$ in marble waste sample.

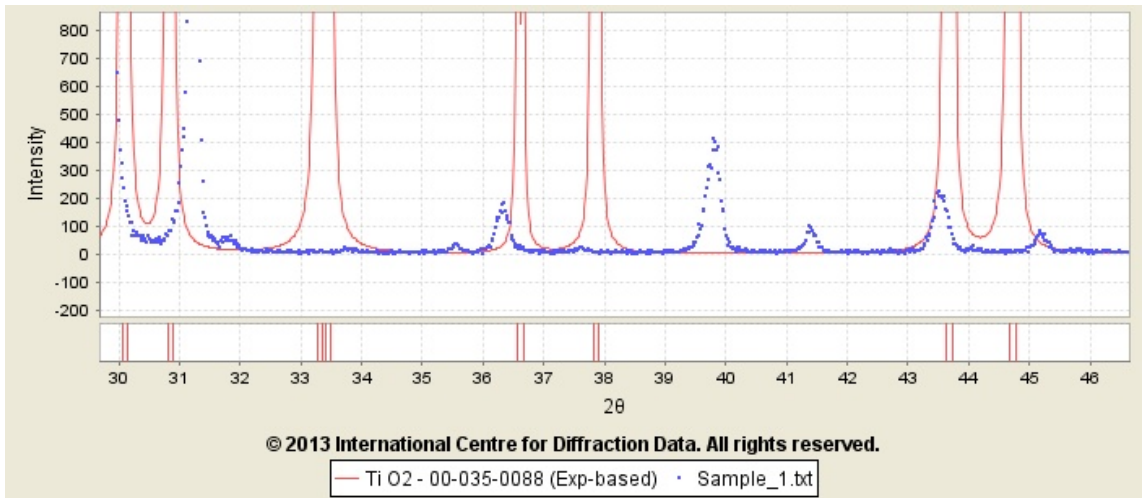

Fig. 4: XRD analysis for $\mathrm{TiO}_{2}$ in marble waste sample. 


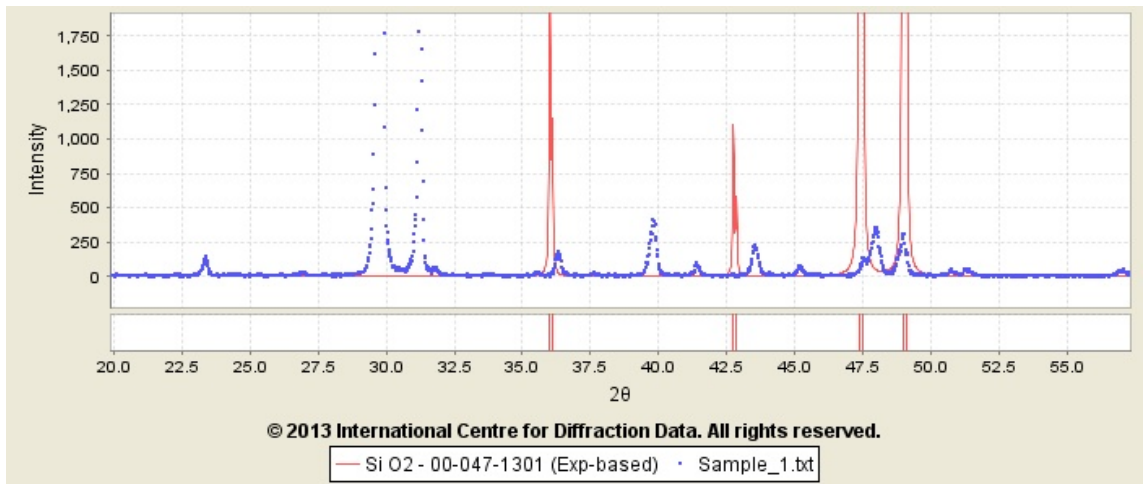

Fig. 5: XRD analysis for $\mathrm{SiO}_{2}$ in marble waste sample.

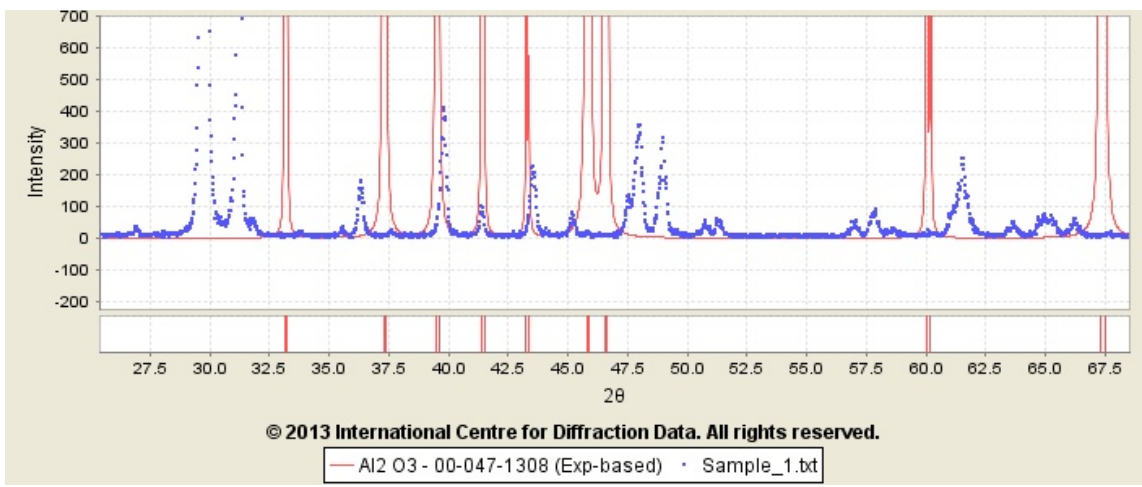

Fig. 6: $\mathrm{XRD}$ analysis for $\mathrm{Al}_{2} \mathrm{O}_{3}$ in marble waste sample.

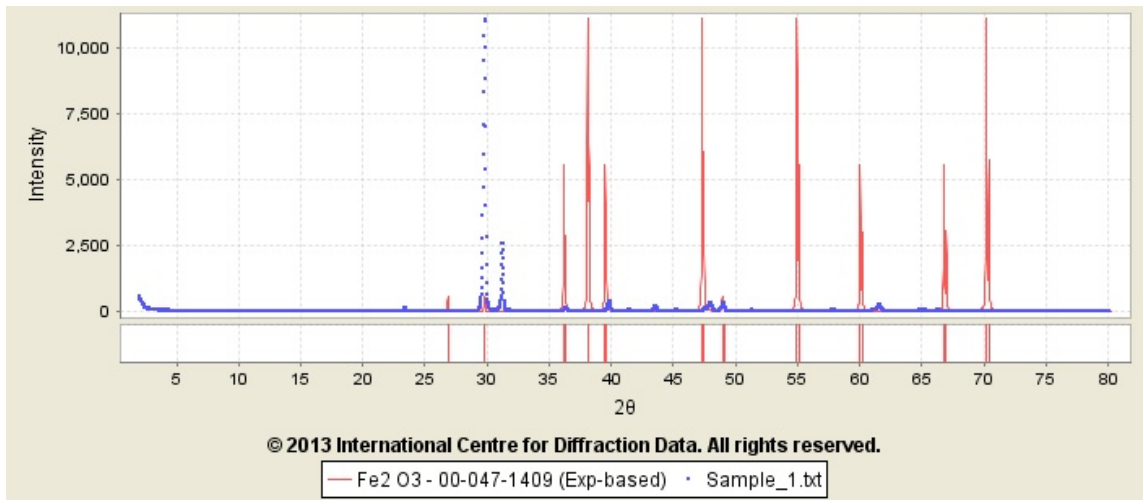

Fig. 7: $\mathrm{XRD}$ analysis for $\mathrm{Fe}_{2} \mathrm{O}_{3}$ in marble waste sample. 


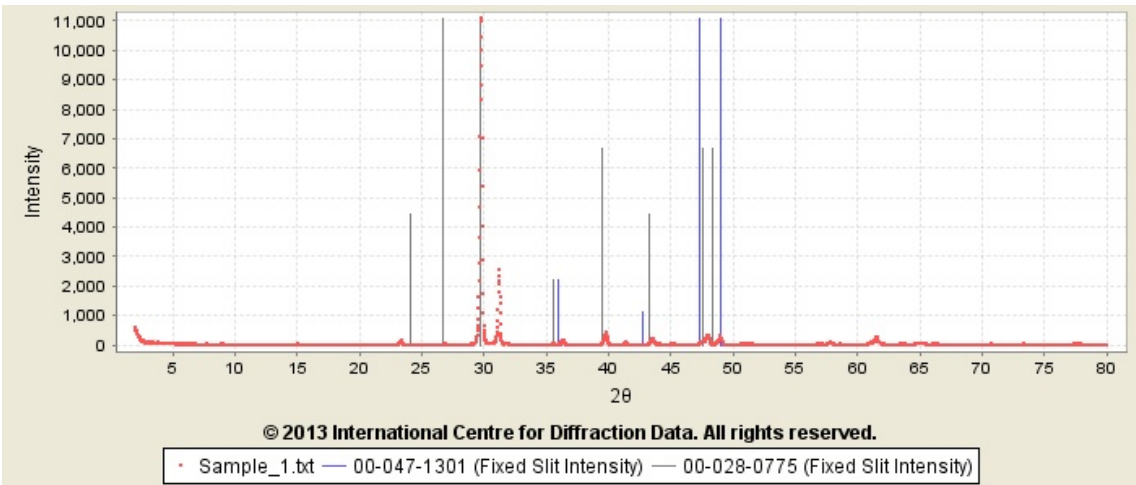

Fig. 8: $\mathrm{XRD}$ analysis for $\mathrm{CaO}$ and $\mathrm{SiO}_{2}$ in marble waste sample.

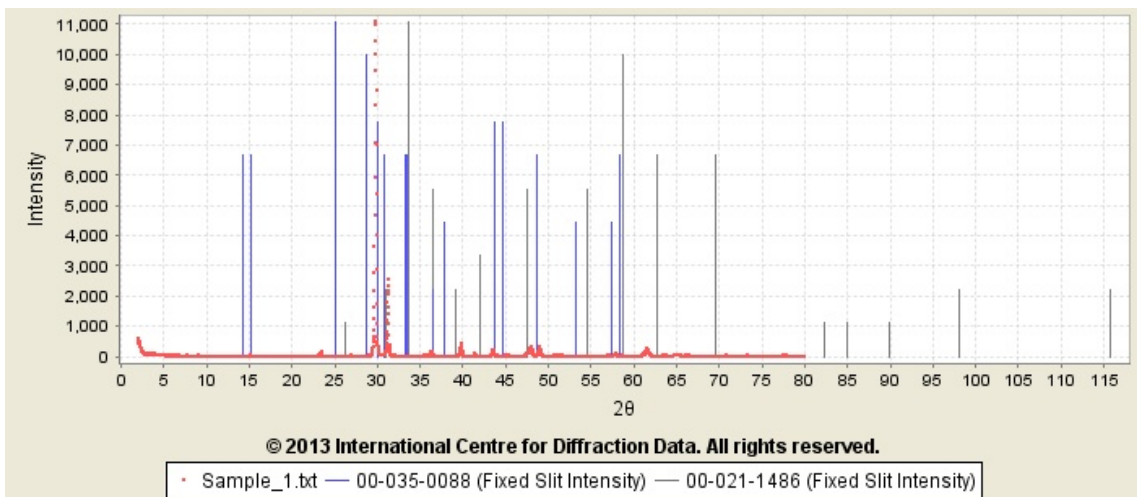

Fig. 9: $\mathrm{XRD}$ analysis for $\mathrm{TiO}_{2}$ and $\mathrm{ZnO}$ in marble waste sample..

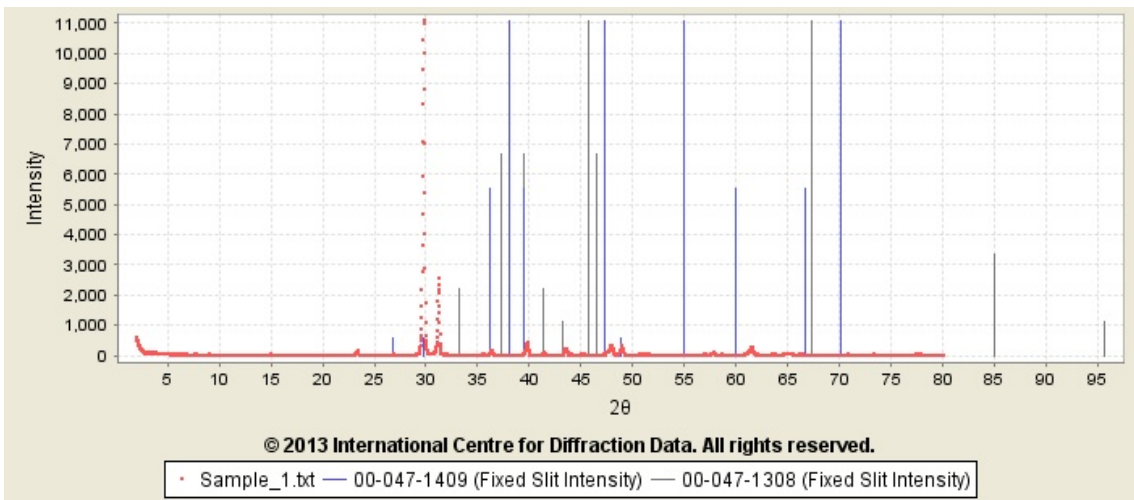

Fig. 10: $\mathrm{XRD}$ analysis for $\mathrm{Al}_{2} \mathrm{O}_{3}$ and $\mathrm{Fe}_{2} \mathrm{O}_{3}$ in marble waste sample.

\subsection{Sieve Analysis of Marble Waste}

Importance of sieving in chemical engineering can observed in produces consistent results and reliable. Despite the minimalist design, test sieves are capable for producing repeatable results regardless of when and where to implement each test. Also, because of their simple 
design, and its very effective data, this type of particle-size analyzer plays an important role in many production facilities, including those found in food processing, pharmaceuticals, cosmetics and chemicals, agricultural and manufacturing industries.

On the other hand, in the sedimentation which is based on the terminal velocity on the liquid particles suspended since the time of deposition is the longest of the minute particles, which means this technique determines the size of the particles as a function of settling.

After experiment have been carried out to analysis the particle size distribution in sieving process. In order to obtain desire product, different aperture has been used in sieving process. It shows that as aperture size of sieve decrease, the cumulative undersize also decrease based on graph obtained.

All eight samples show that porosity is extremely high range between $20 \%$ to $40 \%$. Porosity of the study area changes from the first measured as $0 \mathrm{~m}$ to the last point measured as $80 \mathrm{~m}$. as shown in (figure:1.0) it is assumed that porosity of the study area is stable and the lowest porosity is at the middle of the study area which is at $40 \mathrm{~m}$ distance.

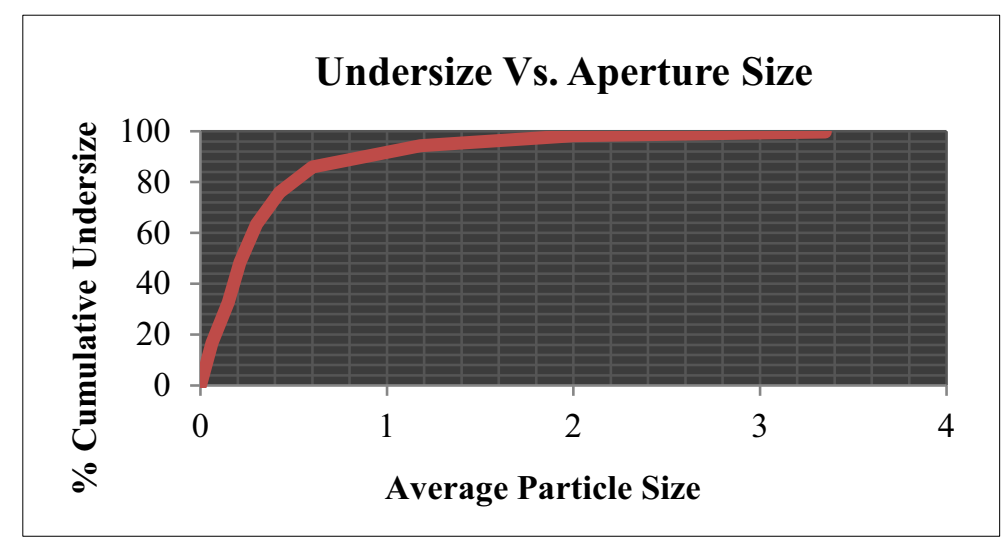

Fig. 11: the relationship between \% Cumulative and Average Particle Size

Table 3: Slump test results for fresh concrete made with marble waste replacement

\begin{tabular}{|c|c|c|c|c|c|c|c|c|}
\hline $\begin{array}{c}\text { Sampl } \\
\text { e date }\end{array}$ & $\begin{array}{c}\text { Marble } \\
\text { Waste } \\
\text { replacemen } \\
\mathrm{t} \%\end{array}$ & $\begin{array}{c}\text { Course } \\
\text { Aggregate } \\
\mathrm{s}(\mathrm{kg})\end{array}$ & $\begin{array}{c}\text { Fine } \\
\text { Aggregate } \\
\mathrm{s}(\mathrm{kg})\end{array}$ & $\begin{array}{c}\text { Cemen } \\
\mathrm{t}(\mathrm{kg})\end{array}$ & $\begin{array}{c}\text { Wate } \\
\mathrm{r}(\mathrm{kg})\end{array}$ & $\begin{array}{c}\mathrm{W} / \\
\mathrm{C}\end{array}$ & $\begin{array}{c}\text { Marbl } \\
\mathrm{e} \\
\text { waste } \\
(\mathrm{kg})\end{array}$ & $\begin{array}{c}\text { Slump } \\
\text { differenc } \\
\mathrm{e}(\mathrm{mm})\end{array}$ \\
\hline $\begin{array}{c}13-05- \\
2013\end{array}$ & 10 & 30.548 & 15.274 & 6.8734 & 4.2 & 0.55 & 0.7637 & 35 \\
\hline $\begin{array}{c}28-05- \\
2013\end{array}$ & 20 & 30.548 & 15.274 & 6.1095 & 4.2 & 0.55 & 1.527 & 30 \\
\hline $\begin{array}{c}11-06- \\
2013\end{array}$ & 30 & 30.548 & 15.274 & 5.346 & 4.2 & 0.55 & 2.2911 & 25 \\
\hline
\end{tabular}

\subsection{Slump test}

As the amount of cement decreased by the incensement in marble waste quantity, the Slump decreased as shown in Figure 4. The reason behind this is that cement reacts with water more than marble waste does. Furthermore, the size of cement particles is much lower than marble waste which affects the packing density of cement. Table 3 shows the slump test results for fresh concrete made with marble waste replacement. 


\subsection{Compaction Factor}

Compaction factor, measures the degree of compaction achieved when a concrete mixture is subjected to a standard amount of work. The compacting factor of concrete of is used to investigate the Workability of Concrete at low, medium and high workability.

A rising in compaction factor is found as the cement replacement increases. This is due to the reduction in cement amount where the cement has better reactivity with water essentially and also with aggregates.

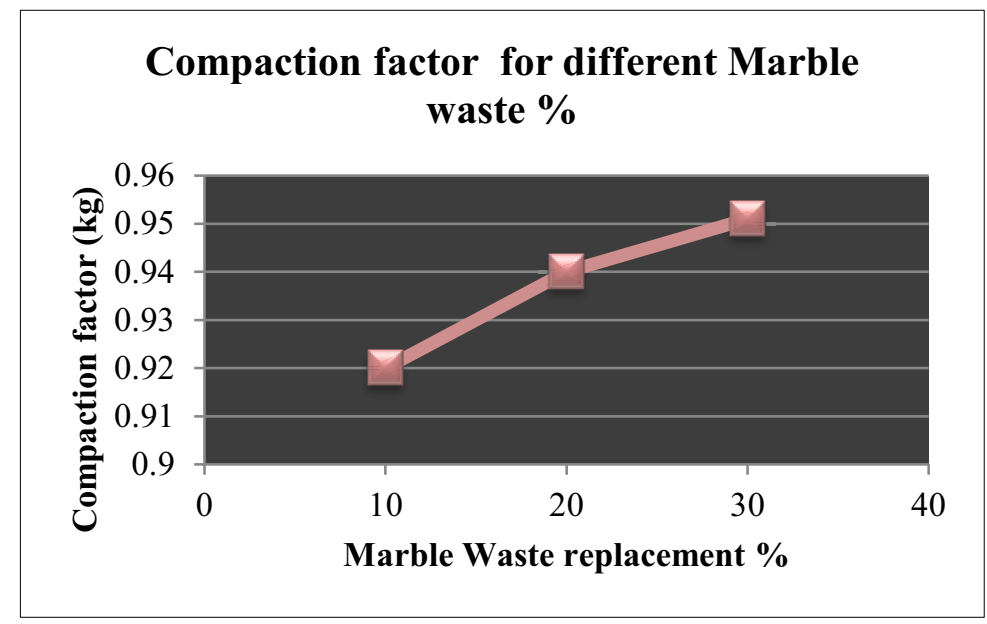

Fig. 12: Compaction factor for different marble waste replacement percentages.

\subsection{Compressive Strength}

Compressive strength of concrete is the most important characteristic property which also affects other concrete properties. Water to Cement ratio and curing age are the main important factors influencing Compressive strength besides compaction. By measuring the load of concrete specimens, we can calculate the value of compressive strength either in Megapascal (MPa) or Pounds per square inch (psi).

For $10 \%$ replacement:

As the substitution percentage is low, no much difference is observed to the results compared to concrete with no marble waste replacement. However, for 14 and 28 days we found almost similar data due to curing conditions. Table 4 shows all measured data while figure 7 present results for easier observation.

For $20 \%$ replacement:

High Compressive strength is observed even with $20 \%$ replacement. This result encourages future works to be done for industry usage. As marble waste quantity increased in concrete mixture it enhances the concrete hardness and this results in good loading properties and thus, such cubes meet the construction requirements. 
Table 4: Compressive strength data for $10 \%$ marble waste.

\begin{tabular}{|c|c|c|c|c|c|}
\hline Specimen & $\begin{array}{c}\text { Curing } \\
\text { days }\end{array}$ & $\begin{array}{c}\text { sample } \\
\text { Curing } \\
\text { start date }\end{array}$ & $\begin{array}{c}\text { sample } \\
\text { Curing } \\
\text { end date }\end{array}$ & $\begin{array}{c}\text { Load } \\
\text { (KN) }\end{array}$ & $\begin{array}{c}\text { Compressive } \\
\text { Strength } \\
\text { (Mpa) }\end{array}$ \\
\hline S-10-7-1 & 7 & $14 / 5 / 2013$ & $21 / 5 / 2013$ & 375 & 16.667 \\
\hline S-10-7-2 & 7 & $14 / 5 / 2013$ & $21 / 5 / 2013$ & 350 & 15.556 \\
\hline S-10-14-1 & 14 & $13 / 6 / 2013$ & $27 / 6 / 2013$ & 350 & 15.556 \\
\hline S-10-14-2 & 14 & $13 / 6 / 2013$ & $27 / 6 / 2013$ & 550 & 24.444 \\
\hline S-10-28-1 & 28 & $14 / 5 / 2013$ & $11 / 6 / 2013$ & 440 & 19.556 \\
\hline S-10-28-1 & 28 & $14 / 5 / 2013$ & $11 / 6 / 2013$ & 460 & 20.444 \\
\hline
\end{tabular}

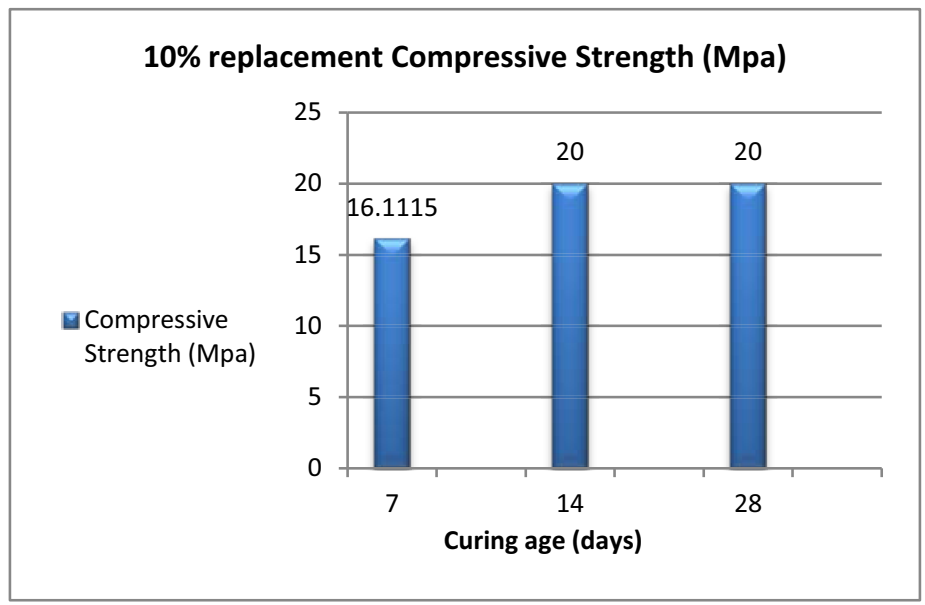

Fig. 7: Compressive strength for Marble waste with $10 \%$ replacement.

Table 5: Compressive strength data for $20 \%$ marble waste.

\begin{tabular}{|c|c|c|c|c|c|}
\hline Specimen & $\begin{array}{c}\text { Curing } \\
\text { days }\end{array}$ & $\begin{array}{c}\text { sample } \\
\text { Curing } \\
\text { start date }\end{array}$ & $\begin{array}{c}\text { sample } \\
\text { Curing } \\
\text { end date }\end{array}$ & $\begin{array}{c}\text { Load } \\
\text { (KN) }\end{array}$ & $\begin{array}{c}\text { Compressive } \\
\text { Strength } \\
\text { (Mpa) }\end{array}$ \\
\hline S-20-7-1 & 7 & $29 / 05 / 2013$ & $5 / 6 / 2013$ & 320 & 14.222 \\
\hline S-20-7-2 & 7 & $29 / 05 / 2013$ & $5 / 6 / 2013$ & 350 & 15.556 \\
\hline S-20-14-1 & 14 & $29 / 05 / 2013$ & $12 / 6 / 2013$ & 420 & 18.667 \\
\hline S-20-14-2 & 14 & $13 / 06 / 2013$ & $27 / 06 / 2013$ & 375 & 16.667 \\
\hline S-20-28-1 & 28 & $29 / 05 / 2013$ & $26 / 06 / 2013$ & 480 & 21.333 \\
\hline S-20-28-2 & 28 & $29 / 05 / 2013$ & $26 / 06 / 2013$ & 430 & 19.111 \\
\hline
\end{tabular}




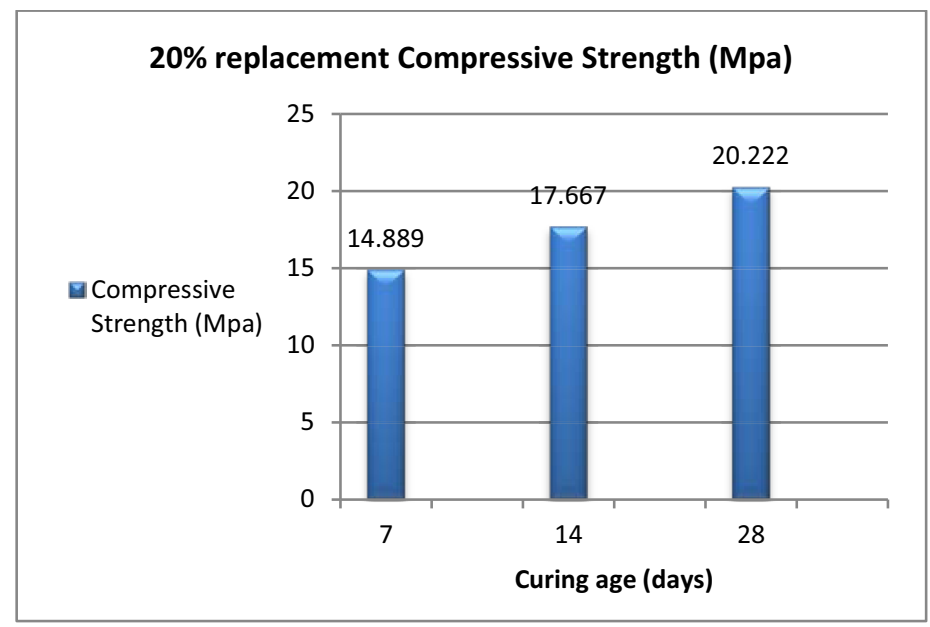

Fig. 8: Compressive strength for Marble waste with $20 \%$ replacement.

For $30 \%$ replacement:

As $30 \%$ of cement is replaced by marble waste, this will result in low loading and compressive strength. The reduction on loading properties is due to the lowering in cementations materials quantity as cement has higher reactivity and water absorption compared to marble waste in such big replacement percentage.

Compressive strength is the most important property not only as a mechanical point of view but in concrete making overall.

Concrete loading is the only way to predict and calculate the compressive strength and by doing so, it is revealed from the above tables and graphs that $20 \%$ replacement is the optimum percentage as it gives around 20 Mpa compared to $10 \%$ and $30 \%$.

For $10 \%$ replacement, there were no much difference between obtained results and fully cementitious concrete and this is due to the slight change in the cement amount compared to $20 \%$ and $30 \%$ replacement.

Compressive strength increases with curing days rising, fair enough, but for $30 \%$ a reduction of the compressive strength value is observed and this is due to the reduction on cement quantity as cement gives the strength to concrete.

Table 6: Compressive strength data for $30 \%$ marble waste.

\begin{tabular}{|c|c|c|c|c|c|}
\hline Specimen & $\begin{array}{c}\text { Curing } \\
\text { days }\end{array}$ & $\begin{array}{c}\text { sample } \\
\text { Curing start } \\
\text { date }\end{array}$ & $\begin{array}{c}\text { sample } \\
\text { Curing end } \\
\text { date }\end{array}$ & $\begin{array}{c}\text { Load } \\
\text { (KN) }\end{array}$ & $\begin{array}{c}\text { Compressive } \\
\text { Strength (Mpa) }\end{array}$ \\
\hline S-30-7-1 & 7 & $6 / 6 / 2013$ & $13 / 06 / 2013$ & 390 & 17.333 \\
\hline S-30-7-2 & 7 & $13 / 06 / 2013$ & $13 / 06 / 2013$ & 370 & 16.444 \\
\hline S-30-14-1 & 14 & $11 / 6 / 2013$ & $25 / 06 / 2013$ & 240 & 10.667 \\
\hline S-30-14-2 & 14 & $11 / 6 / 2013$ & $25 / 06 / 2013$ & 230 & 10.222 \\
\hline S-30-28-1 & 28 & $11 / 6 / 2013$ & $9 / 7 / 2013$ & 220 & 9.778 \\
\hline S-30-28-2 & 28 & $11 / 6 / 2013$ & $9 / 7 / 2013$ & 220 & 9.778 \\
\hline
\end{tabular}




\section{Conclusion}

Recycling of wastes is one of the best solutions now days for environmental protection and for economical and sustainable use of resources. Day by day, the increasing in the consumption of Marble waste can be intuitively observed. This will result in a warning signs to the environment.

The possibility of using marble waste as a partial substitutive to cement in concrete industry has been studied and the effect of this replacement to the mechanical properties of concrete.

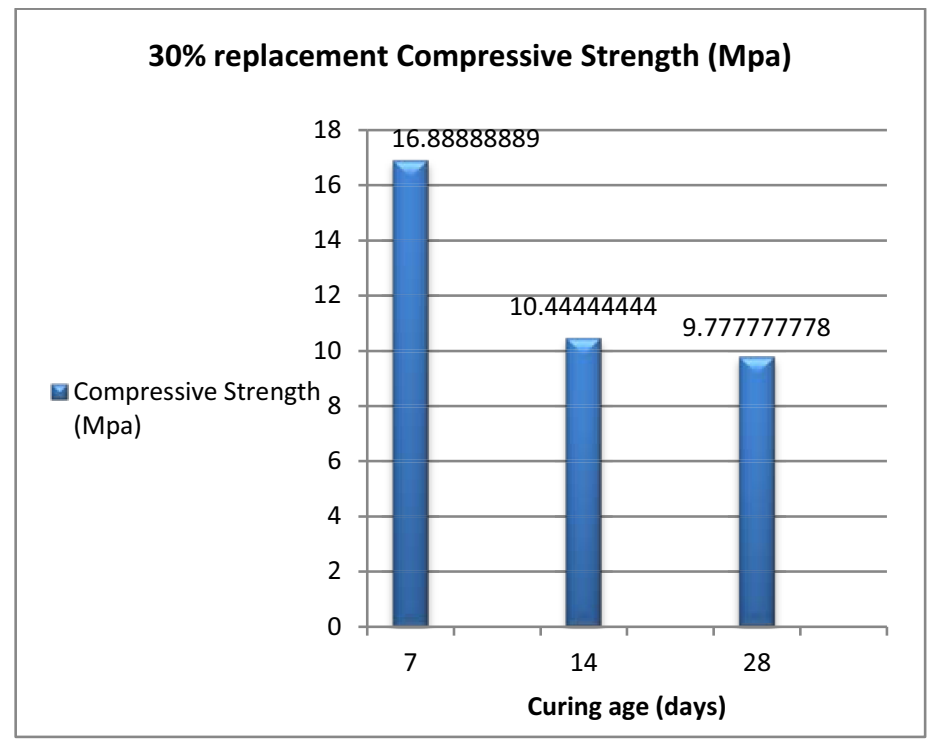

Fig. 9: Compressive strength for Marble waste with $30 \%$ replacement.

The density of concrete which its cement has been replaced partially increase with the rising in the replacement percentage.

From all 18 samples prepared, the $20 \%$ replacement of marble waste is the optimum replacement percentage, and this give a successful of the project.

The XRD (X-Ray diffraction) results it is clear that marble waste is mainly consisting of oxide based components such as:

Silica (SiO2), Calcium (CaO), Phosphorus (P2O5), Magnesium (MgO), Potassium (K2O), Sodium $(\mathrm{Na} 2 \mathrm{O})$, Copper $(\mathrm{CuO})$, Manganese $(\mathrm{MnO})$, Zinc $(\mathrm{ZnO})$, Iron (Fe2O3), Aluminum (Al2O3), Titanium (TiO2) and Sulphur trioxide (SO3).

Experimental works revealed that replacing of Ordinary Portland Cement (OPC) results in reduction in the Slump of the concrete made. This is true for high percentage replacement due to the reduction amount of cement because cement has higher reactivity compared to marble waste.

The study revealed the reduction of Compaction factor with the rising in replacement percentage again this is due to the reduction on the cement.

The study justifies the possibility of the replacement of Cement by marble waste up to $20 \%$ and this could result in reduction of the building cost and the prevention of the environment by the usage of marble waste instead of throwing it out of the city. 


\section{References}

1. N.Krishna Murthy, A.V.Narasimha Rao, M.Vijaya Sekhar Reddy and P.Pamesh (2012), "The Influence of Metakaolin on the Modulus of Elasticity of Concrete", IOSR Journal of Engineering (IOSRJEN), Volume 2, Issue 11 (November 2012), PP 18-23

2. Kamile TOSUN (2009), "Portland Limestone Cement Part I - Preparation of Cements", Digest 2009, December 2009 1337-1355

3. T. W. Bremner (2001), "Environmental aspects of concrete problems and solutions", the 1st All-Russian Conference on Concrete and Reinforced Concrete, 9-14 September 2001.

4. M. Karaşahin, S.Terzi, "Pavement Management System, Past, Present, Future, 4.Asfalt Symposium, Ankara, 2004.

5. Hanifi Binici1 (2007), "Influence of marble and limestone dusts as additives on some mechanical properties of concrete", Scientific Research and Essay Vol. 2 (9), pp. 372379, September 2007[6] Baboo Rai1 (2011), "Influence of Marble powder/granules in Concrete mix", International journal of civil and structural engineering, Volume 1, No 4, 2011

6. ACI 211.1. (1993). "Standard practice for selecting proportions for normal, heavyweight and mass concrete". ACI Manual of Concrete Practice, $38 \mathrm{p}$.

7. Mustafa Yavuz C- elika,_, Eyu p Sabah(2007), "Geological and technical characterisation of Iscehisar (Afyon-Turkey) marble deposits and the impact of marble waste on environmental pollution”, Journal of Environmental Management 87 (2008) $106-116$

8. BS 1881-102:1983Part 2: Slump test, British Standards Institute, London, U.K

9. BS 1881-103:1993, Part 103: Method for determination of compacting factor, British Standards Institute, London, U.K

10. Kryžanowski, A., Šušteršič, J. (2003). "Performance of concrete exposed to long-term underwater abrasion loading”, 21st Congress of International Commission on Large Dams ICOLD Montreal, Proceedings, Q.82-R.13, p. 207-218

11. Shamsad Ahmad (2005), "A study of Permeability and Tortuosity of Concrete", Our world in Concrete and Structure Conference: 23 - 24 August 2005, Singapore

12. Tommy E. Nantung (1998), "Determination of Water-to-Cement Ratio In Fresh Concrete Using Microwave Oven", Indiana Department of Transportation Research

13. Harrison, T. A., Early-Age Thermal Crack Control in Concrete, Report 91, Construction Industry Research and Information Association, London, 1981

14. ACI E701. (2007). “Aggregates for Concrete”. ACI Manual of Concrete Practice, Materials for Concrete Construction

15. ASTM, C 150-04, "Standard Specification for Portland Cement", American Society for

16. Testing Materials", American Society for Testing Materials,USA, 1994.

17. ASTM, C 188-09, "Standard Test Method for Density of Hydraulic Cement", American Society for

18. Testing Materials", American Society for Testing Materials,USA, 1994.

19. ASTM, C 187-11, "Standard Test Method for Amount of Water Required for Normal Consistency of Hydraulic Cement Paste", American Society for Testing Materials", American Society for Testing Materials,USA, 1994.

20. ASTM, C 204-11, "Standard Test Methods for Fineness of Hydraulic Cement by AirPermeability Apparatus", American Society for Testing Materials", American Society for Testing Materials,USA, 1994.

21. Jorge F.Carvalho _, PauloHenriques,Patri'cia Fale', GabrielLu1's (2008), "Decision criteria for the exploration of ornamental-stone deposits: Application to the marbles of 
the Portuguese Estremoz Anticline", International Journal of Rock Mechanics \& Mining Sciences 45 (2008) 1306-1319

22. Valeria Corinaldesi a, Giacomo Moriconi a, Tarun R. Naik (2009), "Characterization of marble powder for its use in mortar and concrete", Construction and Building Materials 24 (2010) 113 